\title{
The Impact of Social Networking on the Oral Performance of EFL Learners
}

\author{
Masoud Qarajeh \\ English Department, Science and Research Branch, Islamic Azad University, Gorgan, Iran \\ Seyed Jalal Abdolmanafi-Rokni (Corresponding author) \\ English Department, Golestan University, Gorgan, Iran \\ E-mail: j.abdolmanafi@gmail.com
}

Doi:10.7575/aiac.alls.v.6n.2p.51

Received: 10/11/2014

URL: http://dx.doi.org/10.7575/aiac.alls.v.6n.2p.51

Accepted: 19/01/2015

\begin{abstract}
The present study was set out to investigate the effect of social hubs on improving EFL learners' speaking skill. The participants of the study were 38 female and 26 male students between the age of 19 and 29. They were randomly assigned to two groups of experimental and control. Each group consisted of 32 participants. A language proficiency test and the pre-test were administered to both groups at the beginning of the study. The treatment lasted three months and it was held in a state university in Gonbad, Iran. The experimental group was allowed and encouraged to use social hubs in addition to the traditional class activities. Further, a course of communication on social networks was administered to the experimental group while the control group attended the traditional regular classes and they were not allowed to use computers for communication. In the end, the post-test was administered to both groups. The findings displayed that social networking had a positive impact on speaking ability of Iranian EFL students.
\end{abstract}

Keywords: Speaking ability, Social hubs, Social Networking Service, EFL Learners

\section{Introduction}

Life is very plane and easy by using new technology. One of the great technologies that has changed the world is the Internet and its power in providing online communication. People use the online communication in doing some regular daily life activities like marketing, connecting to friends and reading news. Electronic communication and computers are things people or students have to deal with every day. The world is engaged with connections. We are linked to the virtual world in which we spend most of our time. We are linked to each other by ordinary and social connections such as relatives as well as by physical and situational conditions. We are also linked to each other by harmonies, joint experiences and the same points of view (Tyson, 2009).

Today there is a vast area of information and knowledge on different aspects of the scientific world over the net. The materials are ready on numerous websites which are definitely useful and helpful for experts and scholars who are working in various fields of science. The Internet has also provided the opportunity to study online. People are joining virtual academies established in which they can participate and learn what is being taught easily. This environment allows them to engage whenever they want. They are free to ask questions and give comments without having any concern that they had in regular and real classes.

Online information is being popular among both academics and the general population. Social networks in education, being a relatively innovative concept has been the central concern of many educationalists, teachers and parents. Moreover, the internet provides opportunities for us to easily publish our research studies.

According to Baran (2013), university students have embraced the capabilities of social media channels. He maintains that based on the statistics a major part of a students' energy and time is devoted to reading formal and informal online texts on various social media channels, watching the videos and following the tweets and updates related to the course content. Twitter also helps students receive updates about recent news and resources related to social media.

Education and training are to discover emerging technologies as new or to improve tools in order to enhance instruction and learning in a way that is considered as a highly useful personal communication technology (Tess, 2013). It is obvious that the way we behave on the web pages has a great impact on what we share and say. It affects how long we speak, and how attentively we speak when on-line. However, online speaking is capturing an increasingly large part of our total speaking time. In this area, Liu and Marchewka (2005) advocated that the age factor contributes to the reading behavior on the net in a way that younger people can spend more time reading the screen-based materials.

Recently some studies were conducted indicating the effects of computer assisted language learning (CALL) on different language skills. Further, some research studies like Lenhart, Arafeh, Smith, Macgill (2008) had a more specific view toward the particular aspects of CALL for different language skills. Their studies proved that using social hubs has a negative effect on academic writing of American learners. As a result, a question may come to mind that how using 
social hubs may affect learners of English as a foreign language and how it would affect different language skills of Iranian EFL students.

Furthermore, Sadaf, Newby, and Ertmer (2012) studied pre-service teachers' ideas about their intention to use the Internet and online communication technologies in their upcoming schoolrooms. The results showed that the majority of the sample was committed to online communication technologies as an educational tool primarily because it can increase students' engagement. In addition, the teachers identified that although they were at ease users of the web technology, they would need directions as how to implement this tool in the educational settings (Tess, 2013).

As the findings of a group of researchers like Lenhart, Arafeh, Smith, Macgill, (2008) show, $88 \%$ of parents with a high school degree or less say that writing online is more important in today's world, compared with $80 \%$ of parents with at least some college experience. They reported that the vast majority of students has eagerly embraced written and oral communication with their partners as they connect and share their information on their social media pages, in email and instant messages or oral short messages online. Moreover, students' mind is engaged with insights and evaluation of social networking sites. They seek a way toward using social networking and they are eager to relate the present state of social networks to their education at school.

As Lenhart et al. (2008) reported, $85 \%$ of teens aged 12-17 involve at least occasionally in one of the electronic personal communication tools. This communication includes short text messaging or instant messages, or posting comments orally on social networking sites. Also, some claim that teens appreciate the ability to work on an issue on computer screens online. Moreover, they remark that social networking sites provide a primary source for research done at or for school. Based on their findings, $94 \%$ of teens use social networking sites sometimes to do research for school.

Pollara and Zhu (2011) showed that a majority of EFL learners learned more than before because of using social networking websites and joining to a social networking group. They claimed that students were interested in using social networking for academic purposes in school. Additionally, students are glad to receive other students' responses about their posts on the net.

Bicen and Uzunboylu (2013) also studied the teachers' perspectives toward using Facebook for educational needs. The findings suggest that teachers agree that social networking websites enable several activaties which are not possible to do in usual settings. The social networking help students improve group working which leads to fine instruction. They also believe that social networking increases students' motivation because they observe themselves in a situation in which they are going to be evaluated by their peers.

According to Tess (2013), education tends to find new technologies as to improve and to enhance instruction and learning. Nowadays the role of new technologies in language learning and teaching is getting more obvious than before. Based on a report by web services, youngsters and juveniles are using social networking websites almost more than class activities.

As people and more subsequently youngsters are using the social networking sites more than ever, it establishes a new area which is so unknown. Studies should be performed upon the consequences of this environment. After the establishment of the new technologies such as social media broadcasting stations, many worked on the post-effect of those. Thus, the present study was set out to discuss the impact of the social networking websites on developing EFL learners' speaking ability.

In Iran as most of the policy makers' focus is on the regular classroom activities, they have ignored the role of students' activities at home and environment. Students are making a huge revolution to become a member of a social network in order to communicate with others. As the students communicate through social networking, they make progress in many abilities. Further, the social networking in the near future might become the main channel to communicate for most of the people all over the world. Moreover, education and training through the Internet is becoming more obvious and common in the world. In many developing countries as well as in Iran, colleges are being interested in online training. They attempt to absorb pupils to use the Internet to perform their training process. The academic institutions need to devise appropriate policies and strategies on how they can utilize social networking sites to support education and learning beyond the classroom.

In order to cover these issues, a study is needed to evaluate the effects of social networking on the particular language ability of Iranian EFL students. This study is an attempt to investigate the effect of using social hubs on improving speaking skill of Iranian EFL learners and how they can develop speaking by emphasizing communication through social hubs. This study is also an attempt to find out the relationship between the application of social networking and speaking skills of Iranian EFL learners. The present study is supposed to have theoretical importance as mentioned below:

1. It is regarded as a top subject to study the effects of the social networking on language learners.

2. Nowadays the scholars show a great deal of attention toward new technology in language learning and teaching.

3. It is the first time one attempts to investigate the relationship between social networking as a new tool in EFL classrooms using a quantitative method.

4. The tendency toward using the social networking is growing than before.

5. Social networking is becoming the most popular method of communicating in schools, so it's beneficial for EFL learners to learn how to communicate using social networks. 
6. Facebook, Moodle, SecondLife, Digg, LinkedIn, and other sites are often used by teachers to communicate with students or for out-of-classroom discussions.

\subsection{Research Question}

Based on the above mentioned problem, the researchers tried to answer the following question:

Does social networking have any effect on the speaking ability of Iranian EFL learners?

\section{Methodology}

\subsection{Participants}

This study was conducted with the participation of the students at Gonbad Kavous University, Iran. There were 32 female and male students in each of the experimental and control groups, they ranged in age from 19 to 29. The sample of this study was chosen from among 110 university students. Students in the study comprised native speakers of Turkmen, Turkish and Persian who were freshman university students. The institute was chosen because it is equipped with many facilities, such as language labs and internet access. To provide at least half of the students with the Internet is one of the vital requirements for conducting the present study. Among the whole population of the experiment, those who obtained one standard deviation below and above the mean were selected. 64 students had the criteria to participate in the study. In order to divide students into the experimental and control groups, the computer randomized procedure was employed. According to the process of randomization, 32 students were chosen to be in the experimental group and the rest were the control group.

\subsection{Instrumentation}

\subsubsection{Oxford Placement Test (OPT)}

This test was administered to determine the language proficiency level of the participants and classify them into the sample. This test consisted of 60 items which was developed by Oxford University Press and University of Cambridge Local Examinations Syndicate. OPT test was used to specify the sample of the experiment among 110 available students in the university of Gonbad.

\subsubsection{TOEFL Speaking Test}

The TOEFL speaking test is the touchstone for measuring the speaking skill of the Iranian EFL learners. It is used at the right beginning of the study as it played the role of pre-test as well as its function as the post-test at the end of the study.

\subsection{Treatment}

\subsubsection{Social Networking Engagement}

In order to apply the treatment on the experimental group, the students joined a social group in the one of the most operative websites. The website WWW.YAHOO.COM and the group made by the author, tefliran/groups.yahoo.com, were selected. Students in the experimental group became a member of the social group 'tefliran/groups.yahoo.com' exactly at the beginning of the study. For the duration of three months and 15 sessions and 45 minutes per a session, they were on the net to communicate with the other members of the group. In every session on the net, the experimental group took part in the discussion and shared their ideas through messaging and giving comments. In this social group, the participants were actively present in each session on the net.

\subsection{Procedure}

In order to determine the role of social hubs on the speaking ability of students, Oxford Placement Test was administered among 110 young learners out of whom those whose scores were between one SD below and above the mean were selected for the study. The participants were assigned to two groups randomly. After the pre-test, learners received the instruction based on the materials covered in the class. The experimental group had the chance to work with social hubs in addition to the traditional class activities but the control group did not have this opportunity and just had the traditional class activities. Finally, the learners were administered the TOEFL speaking used as the post-test at the end of the treatment.

\section{Results}

In order to have homogenized participants in terms of their general English language proficiency, the Oxford Placement Test was administered. The descriptive statistics for the OPT test are displayed in following table.

Table 1. The Descriptive Statistics of the OPT Test

\begin{tabular}{lll}
\hline $\mathrm{N}$ & Valid & 110 \\
\cline { 2 - 3 } & Missing & 0 \\
Mean & & 69.9182 \\
Median & 69.0000 \\
Std. Deviation & 12.70565 \\
Variance & 161.434 \\
Minimum & 38.00 \\
Maximum & 95.00 \\
\hline
\end{tabular}


Out of 110 participants, 70 were considered as homogenous members based on one SD above and one SD below the mean. Figure 1 below shows the histogram for the OPT test.

Before working on the research question, it should be mentioned that the speaking test section was rated using two raters holding M.A. in TEFL. Table 2 below shows the inter-rater reliability.

Table 2. Inter-rater reliability between the two scorers

\begin{tabular}{lll}
\hline Cronbach's Alpha & $\begin{array}{l}\text { Cronbach's Alpha Based on Standardized } \\
\text { Items }\end{array}$ & N of Items \\
\hline .809 & .818 & 2 \\
\hline
\end{tabular}

As it can be seen in table 2, the inter-rater reliability index is .809 which shows high reliability between two scorers.

In order to answer the question of the study, an independent sample test was run to compare the scores of students in the experimental and control group. The data revealed that there was no significant difference between the speaking ability of the two groups. As it is shown in table 3, $\mathrm{t}(0.45)=.045, \mathrm{p}=.045<.05$ showing that there was no significant difference in students' speaking ability at the beginning of the study.

Table 3. Independent Samples Test

\begin{tabular}{|c|c|}
\hline $\begin{array}{l}\text { Levene's Test for } \\
\text { Equality of } \\
\text { Variances }\end{array}$ & t-test for Equality of Means \\
\hline
\end{tabular}

\begin{tabular}{|c|c|c|c|c|c|c|c|c|}
\hline & & $\mathrm{F}$ & Sig. & $\mathrm{t}$ & Df & $\begin{array}{l}\text { Sig. } \\
\text { tailed) }\end{array}$ & $\begin{array}{l}\text { (2-Mean } \\
\text { Difference }\end{array}$ & Std. Error Difference \\
\hline \multirow[t]{2}{*}{ Pre-test } & $\begin{array}{l}\text { Equal } \\
\text { variances } \\
\text { assumed }\end{array}$ & .357 & .552 & .045 & 62 & .964 & .06250 & 1.38165 \\
\hline & $\begin{array}{l}\text { Equal } \\
\text { variances } \\
\text { assumed }\end{array}$ & & & .045 & 61.548 & .964 & .06250 & 1.38165 \\
\hline
\end{tabular}

In order to answer the research question, an independent t-test was also run to compare the means of the two groups after applying the treatment for the experimental group and a placebo for the control group. Table 4 below shows the result.

Table 4. Result of the independent t-test

\begin{tabular}{ll}
\hline Levene's Test for \\
Equality of Variances t-test for Equality of Means \\
\hline
\end{tabular}

\begin{tabular}{|c|c|c|c|c|c|c|c|c|}
\hline & & $\mathrm{F}$ & Sig. & $\mathrm{t}$ & $\mathrm{df}$ & $\begin{array}{l}\text { Sig. } \\
\text { tailed) }\end{array}$ & $\begin{array}{l}\text { 2-Mean } \\
\text { Difference }\end{array}$ & Std. Error Difference \\
\hline $\begin{array}{l}\text { Con- } \\
\text { Exp }\end{array}$ & $\begin{array}{l}\text { Equal } \\
\text { assumed }\end{array}$ & variances 2.318 & .133 & 4.880 & 62 & .00 & 6.31250 & 1.29355 \\
\hline Scores & $\begin{array}{l}\text { Equal v } \\
\text { assumed }\end{array}$ & Inces not & & 4.880 & 56.840 & .000 & 6.31250 & 1.29355 \\
\hline
\end{tabular}

As it can be seen in table $4, \mathrm{t}(62)=4.88, \mathrm{p}=.000<.05$. Therefore, the independent $\mathrm{t}$-test shows that there is a statistically significant difference between the post scores of the experimental and control groups. Hence, it can be concluded that the null hypothesis "Social networking has no effect on the speaking ability of Iranian EFL learners" is rejected.

In order to find the difference between the pretest and posttest scores of the experimental group, a paired-samples t-test was run. Table 5 shows the result. 


$95 \%$ Confidence
Interval of the
Difference

\begin{tabular}{llllllllll}
\multicolumn{2}{c}{ Std. } & \multicolumn{2}{l}{ Std. Error } & & & & \\
& & Mean & Deviation & Mean & Lower & Upper & t & df & Sig.(2-tailed) \\
\hline Ppairs & $\begin{array}{l}\text { Exppretest } \\
\text { Expposttest }\end{array}$ & -9.65625 & 1.51571 & .26794 & -10.20272 & -9.10978 & 36.039 & 31 & .000 \\
\hline
\end{tabular}

As it can be seen in table $5, \mathrm{t}(31)=36.039, \mathrm{p}<.05$. Therefore, it is concluded that there was a statistically significant difference between the pretest and posttest scores of the experimental group after receiving the treatment.

\subsection{Discussion}

The finding of this study is in line with the results obtained by Rambe (2011). In line with the finding of Rambe (2011) who worked more specifically on the influence of social networking services on power lecture, this study was engaged more with the influence of SNS on a language skill.

More consistently, Clark and Gruba (2010) obtained the same results as the present study. They claimed that using social networks is one of the effective ways to enhance foreign language learning. These findings are the same with the research conducted by Kirschner and Karpinski (2010). Their experiment illustrated that there is a direct relationship between social networking site usage and the progress in academic performance of students. Among the 148 university pupils, it was concluded that Facebook users not only had a much lower Grand Point Average. Nevertheless, other studies such as Cohen (2007) showed completely opposite results. His study has been unable to prove any connections between GPA and SNS wide usage.

According to the findings of the study done by Naditz (2009), there are numerous apparent advantages based on her experiences with integrating social networking sites in foreign language classrooms. First, using social networks tend to have a significant impression on language learning. The second benefit is that it helps students engage with peers in a familiar way and for academic purposes. More significantly for language learners, it provides opportunities for informal conversations in the target language.

Further, Hung and Yuen (2010) pointed out that educational usage of social networking websites indeed positively affect educational performance of the students. Like study it was concluded that social networking affect students' oral performance.

Further, a study conducted by Stanciu, Mihai and Aleca (2012) described the social networking as an alternative environment in which the students at higher levels of education develop their knowledge. The same results were also concluded by the present research.

\section{Conclusion}

Social networking in Iran is regarded as an entertaining device for the non-educational purposes. With the great influence that the Internet and social networking had on people's life, no one can ignore the role of the new technology in education. The attitude toward practical usage of social networks should be one of the priorities of the policy makers. This paper wants to establish a movement to enhance the role of the social networking in educational settings.

The social networking websites are gaining wider acceptability and usability among university students and trainers. It is also becoming perhaps the most popular connective tool among students not only at the higher levels of education but also in high school settings. Social media have the capacities of influencing the world in a very short time regardless of the distance. On the basis of its abilities, benefits and disadvantages this study was set out in order to show the potentials of social networking websites in the academic setting.

Social networking provides a comfortable interface for speakers as students, collogues and teachers. As they connect, they are able to share the Internet links and multimedia such as photos or videos with each other. This could allow the teacher to facilitate discussion among students of the target language and culturally relevant material. While students connect to the social networking sites, it is important to explore how these can be applied specially in the foreign language classroom settings.

The social networking websites may be adopted into special curriculum. Further research can focus on the way to adopt the social networking into a useful curriculum. The ways to benefit the social networking websites should be explored. Additionally, it is recommended that the social networks and its consequences can be discussed in different educational settings. As few studies focused on the teachers' perspectives toward the application of the social networks as educational tools, it may be a subject for research.

\subsection{Pedagogical Implications}

The present decade is engaged widely with the usage of social networks. According to the results of the present study, most of the students know how to use social networks in order to communicate. University faculty members and 
instructors are using the social networks as to save time and energy. The world is becoming a rural area in which one can find whomever he wants on the net.

Language teaching and learning is one of the main fields that can benefit from the social networking sites. The main goal of this study was to find the effect the social networking sites have on one language skill, speaking. As a result, it is hoped that a proper method is established to direct the new technology toward a model in which both of the students and teachers may improve their performance. The following pedagogical implications can be made based on the findings of this study:

1. Teachers and trainers of foreign languages should make use of social networking as a part of their teaching syllabuses to improve their language skills. The students can also benefit from the knowledge sharing on the net rapidly.

2. Language learners can use social networking for their self-assessment outside the classrooms to enhance their skills. Using social networking sites not only helps students practice individually but also for their friends and classmates it provides a partner.

3. The Ministry of Science, Research and Technology in Iran can provide such opportunity to engage at least students' free time so that they can enjoy being in touch with each other. This way they can make use of most of their time spending on their improving language skills.

4. The use of social networking sites can also help teachers easily evaluate students' progress during the instruction process.

5. Using social networks can decrease the anxiety of the learners in an EFL classroom because it was concluded that the communication through social networks is more comfortable according to the questionnaire survey that was performed by the author of the present study and findings of others.

\section{References}

Baran, E. (2013). Connect, participate and learn: Transforming pedagogies in higher education. Bulletin of the IEEE Technical Committee on Learning Technology, 15(1), 9-12.

Behler, A. (2009). E-readers in action. American Libraries 40(10), 56-59.

Bicen, H \& Uzunboylu, H. (2013). The Use of Social Networking Sites in Education: A Case Study of Facebook. Journal of Universal Computer Science, 19(5), 658-671.

Boyd, D.M. \& Ellison, N.B. (2007). Social network sites: Definition, history, and scholarship. Journal of ComputerMediated Communication 13(1), 210-230.

Clark, C. \& Gruba, P. (2010). The use of social networking sites for foreign language learning: An autoethnographic study of Livemocha. In Proceedings of ASCILITE - Australian Society for Computers in Learning in Tertiary Education Annual Conference 2010 (pp. 164-173).

Cohen, D. (2007). Facebook for scientists? British Medical Journal, 335(76), 401. Retrieved September 26, 2014, from JSTOR database.

Cushman, W.H. (1986). Reading from microfiche, a VDT, and the printed page: subjective fatigue and performance. Human Factors, 28(1), 63-73.

Hung, H \& Yuen, S. (2010). Educational use of social networking technology in higher education. Teaching in higher educational, 15(6), 703-716.

Kirschner, P.A. \& Karpinski, AC. (2010). Facebook and academic performance. Computers in Human Behavior, Elsevier Ltd, USA, 26, 1237-1245.

Lenhart, A., Arafeh, S., Smith, A. \& Rankin Macgill, A. (2008). Writing, technology and teens. Retrieved September 12, 2014 from http://www.pewinternet.org.

Liu, C., Marchewka, J.T., Lu, J., \& Yu, C.Y. (2005). Beyond Concerns: A Privacy-Trust Behavior Intention Model. Information \& Management (I\&M), 42(1), 289-304.

Naditz, A. (2009). In the Green: Here Comes the Sun (and Wind), Sustainability initiatives at community colleges.

Sustainability. Retrieved September 15, 2014, from

https://www.actfl.org/sites/default/files/pdfs/TLEsamples/TLE_Nov11_Article.pdf.

Pollara, P. \& Zhu, J. (2011). Social Networking and Education: Using Facebook as an Edusocial Space. In Proceedings of Society for Information Technology \& Teacher Education International Conference 2011 (pp. 3330-3338). Chesapeake, VA: AACE.

Rambe, P. (2011). Critical discourse analysis of collaborative engagement in Facebook postings. Australasian Journal of Educational Technology, 28(2), 295-314.

Sadaf, A., Newby, T.J., Ertmer, P.A. (2012). Exploring Factors that Predict Preservice Teachers' Intentions to Use Web 2.0 Technologies Using Decomposed Theory of Planned Behavior. Journal of Research on Technology in Education, 45(2), 171-195.

Tess, P.A. (2013). The role of social media in higher education classes (real and virtual)-A literature review. Computers in Human Behavior, 29(5), 60-68.

Tyson, J. (2009). The influence of social networking on communication. Unpublished M.A thesis. Winston-Salem University, North Carolina. 